\title{
RESEARCH OF DIGITAL LITERACY OF POPULATION IN THE SLOVAK REPUBLIC
}

Mojmír KOKLES, Ekonomická univerzita v Bratislave, Slovenská republika Anita ROMANOVA, Ekonomická univerzita v Bratislave, Slovenská republika

Michal ZELINA, Ekonomická univerzita v Bratislave, Slovenská republika Anna HAMRANOV $\boldsymbol{A}^{*}$, Ekonomická univerzita v Bratislave, Slovenská republika

Přijato: 15. 11. 2016 / Akceptováno: 1. 2. 2017

Typ článku: Výzkumná studie

DOI: $10.5507 /$ jtie.2017.002

Abstract: The aim of the article is to analyse available publications, as well as official documents of European Commission dealing with the term digital literacy, to define digital abyss and factors which affect it. The article further focuses on investigation of digital literacy in SR, as well as on determining the effect of selected factors. There were used general methods of scientific research, questionnaire, survey of digital literacy in Slovakia, statistical evaluation and verification of statistical significance. The findings of the research confirmed that the expected factors, which are predominantly age and education, affect the creation of digital abyss in Slovakia.

Key words: knowledge society, digital literacy, digital skills, digital divide

\section{VÝSKUM DIGITÁLNEJ GRAMOTNOSTI POPULÁCIE V SLOVENSKEJ REPUBLIKE}

Abstrakt: Ciel'om príspevku je analyzovat' dostupnú literatúru, ako aj oficiálne dokumenty Európskej komisie, zaoberajúce sa pojmom digitálna gramotnost, charakterizovat' digitálnu priepast' a faktory, ktoré ju ovplyvňujú. Príspevok je d'alej zameraný na výskum úrovne digitálnej gramotnosti v SR, ako aj na zistenie vplyvu vybraných faktorov. Použité boli všeobecné metódy vedeckej práce, dotazníkový prieskum digitálnej gramotnosti na Slovensku, štatistické vyhodnotenie a overenie štatistickej významnosti. Závery výskumu potvrdili, že aj na Slovensku ovplyvňujú vytváranie digitálnej priepasti predpokladané faktory, ktorými sú predovšetkým vek a vzdelanie.

Klíčová slova: znalostná spoločnost', digitálna gramotnost', digitálne zručnosti, digitálna priepast'

\footnotetext{
* Korešpondenčný autor: anna.hamranova@euba.sk
} 


\section{1 Úvod}

Budovanie informačnej a znalostnej spoločnosti je stredobodom záujmu všetkých vyspelých štátov sveta, ako aj Európskej únie. Je to trend, ktorý je podmienený technologickým rozvojom a premenou tradičnej priemyselnej výroby na oblast' spracovania a využívania informácií. Informačno-komunikačné technológie (IKT) ovplyvňujú rôzne aspekty každodenného života, v práci aj v domácnostiach, na ktoré reagujú aj politiky Európskej únie.

V máji v roku 2010 prijala Európska komisia dokument „Digitálna agenda pre Európu“, v ktorom predstavila stratégiu na podporu digitálnej ekonomiky do roku 2020. Je v nej načrtnutých sedem prioritných oblastí: vytvorenie jednotného väčšia digitálneho trhu, interoperabilita, zvýšenie dôveryhodnosti a bezpečnosti internetu, rýchlejší prístup na internet, vyššie investície do výskumu a vývoja, zlepšenie digitálnej gramotnosti a inklúzie a uplatňovanie informačných a komunikačných technológií pri riešení problémov, ktorým spoločnost' čelí, ako sú zmena klímy a starnúca populácia (Európska komisia, 2010). Prijímaním akčných plánov plánujú európske inštitúcie naplno využit' IKT na urýchlenie hospodárskeho oživenia a položenie základov udržatel'nej digitálnej budúcnosti.

Potreba nových znalostí, zručností a demografické zmeny, ktorým Európa čelí, zdôraznili význam vzdelávania dospelých v stratégii celoživotného vzdelávania, ako aj vzdelávania mladých l'udí. V dokumente „Nový impulz pre európsku spoluprácu v oblasti odborného vzdelávania a odbornej prípravy na podporu stratégie Európa 2020“ je sformulovaných 11 strategických ciel'ov na naplnenie vízie v tejto oblasti (Eurostat, 2015).

Digitálne občianstvo, ako jeden z d'alších dôležitých dokumentov EÚ, si vyžaduje, aby digitálne gramotní užívatelia disponovali zručnost'ami vo využívaní IKT a d'alších aplikácií. Okrem nich sa vyžaduje aj digitálna gramotnost' ,ako schopnost' efektívne hl'adat', hodnotit', používat' a vytvárat' informácie za účelom dosiahnutia osobných, sociálnych, profesijných a vzdelávacích ciel’ov“(Gruszcynska a kol., 2013).

Koncept znalostnej spoločnosti, ktorý vyzdvihuje význam IKT prináša množstvo výhod ale aj d'alšie skôr nepredpokladané dôsledky, ku ktorým zarad'ujeme predovšetkým prístup k IKT, ktorý sa tak v súčasnosti stáva dôležitým faktorom. Medzi tými, ktorí prístup k IKT majú a tými, ktorí nemajú, vznikajú rozdiely, ktoré sa označujú pojmom digitálna priepast'. OECD definuje digitálnu priepast' ako „termín používaný na označenie priepasti medzi jednotlivcami, domácnost’ami, firmami aj geografickými priestormi na rôznych socioekonomických úrovniach zohl'adňujúcich ich príležitosti na prístup a využitie IKT akými sú počítače a internet" (OECD, 2004).

V dokumente „Information society statistics at regional level“ (Eurostat, 2015) sa tiež uvádza, že na začiatku digitálnej revolúcie bol prístup k internetu obmedzený na tých, ktorí pracovali s počítačom alebo počítač vlastnili. Následný technologický vývoj spôsobil vznik väčšieho počtu inteligentných zariadení s pripojením na internet. Predpokladá sa, že rozšírenie inteligentných telefónov, tabletov a d'alších inteligentných zariadení pomohlo premostit' digitálnu priepast' tým, že umožnilo prístup k internetu aj tým skupinám l'udí, ktorí predtým prístup nemali, napr. skupiny s nižším vzdelaním alebo osoby s nízkymi príjmami. 
V dokumente „Digitálna agenda pre Európu“ (Európska komisia, 2010) je stanovený ciel' pre rok 2015, že podiel populácie krajín EU-28, ktorá nikdy nepoužila internet by mal byt' menší ako $15 \%$. Podla údajov z roku 2015 (Eurostat, 2015) je toto číslo $16 \%$, čo je len o $1 \%$ viac ako stanovený ciel' a $11 \%$ menej ako pred piatimi rokmi v roku 2010.

V zmysle strategických dokumentov a operačného programu Informatizácia spoločnosti v Slovenskej republike (Operačný program Informatizácia spoločnosti verzia 4.0, 2012) dochádza budovaním znalostnej spoločnosti k postupnej premene jej tradičného vnímania ako znalostného trojuholníka, ktorý je tvorený - vzdelávaním, výskumom a inováciami; na štvoruholník v ktorom d’alšiu stranu predstavuje informatizácia. Zavádzanie IKT a následne zefektívňovanie procesov ich využívania sa podiel’a na dosiahnutí vyššej efektívnosti a účinnosti implementácie prvkov znalostnej spoločnosti. Hlavné ciele $\mathrm{v}$ tejto oblasti sú zadefinované takto:

- digitálna gramotnost',

- efektívna elektronizácia verejnej správy,

- $\quad$ široká dostupnost' internetu.

Doterajší vývoj, ako aj aktuálny stav vybavenosti slovenskej populácie počítačmi a prístupom na internet, sú predpokladom toho, že bola dosiahnutá základná nasýtenost' slovenskej spoločnosti novými IKT. Podl'a prieskumu spoločnosti Google Slovensko je „Internet pre Slovákov neoddelitel'nou súčastou života. Až tri štvrtiny slovenských používatel'ov internetu sa $\mathrm{k}$ nemu pripája pravidelne. $61 \%$ respondentov priznalo, že sa pripája na internet každý deň, pričom takmer polovica občanov SR si už život bez internetu nedokáže predstavit“" (Google Slovensko, 2014).

Aj ked' nie je populácia plošne novými technológiami plne vybavená, miera vybavenosti dovol'uje vyslovit' predpoklad, že sociálne, profesijné a vzdelanostné skupiny, ktoré sú nositel'mi ekonomických a iných hodnôt, v súčasnosti aj perspektívne v budúcnosti, budú novými IKT disponovat'. Nutnou podmienkou k správnemu využívaniu IKT je primeraná úroveň digitálnej gramotnosti. Dôležitú úlohu v oblasti zvyšovania informačnej a digitálnej gramotnosti zohráva školský a vzdelávací systém. „Fundamentom informačného vzdelávania sú všetky stupne škôl a klúčovým sú vysoké školy, ktoré pripravujú študentov - budúcich odborníkov pre prax v oblasti informatiky a IKT“ (Bolek, 2015).

\section{Digitálna gramotnost'}

Zadefinovanie pojmu digitálna gramotnost' je pomerne t'ažké, a to z toho dôvodu, že predmet digitálnej gramotnosti sa neustále vyvíja. Prvá definícia pojmu pochádza z roku 1997, kedy P. Gilster zadefinoval pojem digitálnej gramotnosti ako „schopnost' porozumiet' a použivat' informácie v rôznych formátoch zo širokej škály zdrojov, ktoré sú získavané (poskytované) prostredníctvom počítača“ (Gilster, 1997). Rýchly vývoj v oblasti IKT sa prejavuje aj v pohl'ade na d'alšie definície, ktoré rešpektujú aktuálny stav v oblasti IKT. Podl'a M. Velšica, digitálna gramotnost' vo všeobecnosti zahíňa schopnost' porozumiet' informáciám a použivat' ich $\mathrm{v}$ rôznych formátoch $\mathrm{z}$ rôznych zdrojov prezentovaných prostredníctvom moderných IKT (Velšic, 2011). Organizácia ECDL Foundation v materiáli Budovanie digitálne gramotnej Európy prostredníctvom vzdelávania, charakterizuje pojem „digitálna gramotnost’ ako súbor zručností potrebných 
na efektívne používanie dostupných technológii vrátane počitačov“ (ECDL Foundation, 2010).

Autori učebnice „Digital Futures in Teacher Education“ uvádzajú, že aj napriek tomu, že sa interpretácie kritickej gramotnosti líšia, zdiel’ajú spoločný názor na potrebu zahrnutia kritickej dimenzie do výučby a zamerania sa na sociálne účely gramotnosti. Trendom v oblasti digitálnej gramotnosti je inštrumentálny pohl’ad, rozšírený o politické a sociálne aspekty gramotnosti (Gruszcynska a kol., 2013).

Pojmom digitálna resp. počítačová gramotnost' možno teda vo všeobecnosti rozumiet' kompetenciu ovládania a využívania IKT. Digitálne gramotný človek je schopný používatel'sky využívat' IKT bez toho, aby rozumel technologickým princípom fungovania počítačov a prenosových zariadení. Počítačovo gramotný človek je schopný pracovat' $\mathrm{s}$ najčastejšie využivaným programovým vybavením, používat internet v komunikácii, pri vyhl'adávaní a spracovaní informácií, využívat' služby a možnosti, ktoré mu IKT ponúkajú a poznat' účel a spôsob ich aplikovania.

Vedecká stat' vychádza z vyššie uvedených dokumentov a jej základom je výskum úrovne digitálnej gramotnosti na vybranej vzorke občanov Slovenska starších ako 18 rokov. Hlavným ciel'om vedeckej state je prezentovanie výsledkov tohto výskumu. Čiastkovými ciel'mi sú: vyhodnotenie jednotlivých skúmaných ukazovatel’ov, overenie štatistickej významnosti, identifikácia problémových oblastí (digitálnej priepasti) a určenie zdroja získaných znalostí a zručností z oblasti IKT.

\section{Použité metódy}

Pre splnenie hlavného ciela a čiastkových ciel'ov boli použité všeobecné metódy vedeckej práce, akými sú analýza, syntéza, komparácia, indukcia a dedukcia (Gavora a kol., 2010) Uvedené metódy boli aplikované pri štúdiu domácich a zahraničných teoretických zdrojov, ako aj pri získavaní sekundárnych štatistických údajov údajov z databáz Eurostatu a z databáz poskytovaných Štatistickým úradom SR.

Zber primárnych údajov bol realizovaný dotazníkovým prieskumom. Údaje boli d’alej spracované v programe MS Excel a vyhodnotené štatistickými metódami.

Dotazníkový prieskum pozostával celkovo z 27 otázok (ukazovatel’ov), rozdelených do 3 kategórií, ktorými sme pokryli tieto podla nás dôležité oblasti IKT: hardvér (A1, A2,..A4), softvér (B1, B2,.B12), práca v prostredí internetu (C1, C2, C11). Pri tvorbe otázok sme vychádzali z už realizovaných prieskumov (Eurostat, 2012; Velšic, 2011), ako aj $\mathrm{z}$ aktuálneho štúdia literatúry a vlastných poznatkov. Stupeň ovládania jednotlivých ukazovatel'ov respondenti určovali na základe samohodnotenia, pričom vychádzali zo stanovenej stupnice. Meranie úrovne digitálnych zručností bolo realizované na hodnotiacej stupnici od 1 do 5 , pričom hodnotenie 1 zodpovedalo „ovládam vel’mi dobre“, hodnotenie 5 „neovládam vôbec“. Celková úroveň digitálnej gramotnosti bola stanovená priemerom dosiahnutých hodnôt jednotlivých ukazovatel'ov. Rovnako aj úroveň digitálnej gramotnosti jednotlivých kategórií. Systém ukazovatel'ov, ich označenie použité pri štatistickom vyhodnocovaní a čiastkové výsledky, sú uvedené v tab. č.2.

$\mathrm{Na}$ spracovanie, vyhodnotenie údajov a na overenie štatistickej významnosti boli použité štatistické metódy využitím štatistického softvéru IBM SPSS. Konkrétne to boli tieto metódy: 
- základný štatistický aparát - deskriptívna štatistika,

- $\quad$ t-test pre 2 nezávislé výbery (Independent Samples $\mathrm{t}$ - test),

- jednokriteriálna a multikriteriálna analýza ANOVA.

\section{Priebeh a výsledky riešenia}

Priebeh a výsledky riešenia sú podrobne rozpracované v podkapitolách 4.1 až 4.3.

\subsection{Charakteristika výskumnej vzorky}

Výskumnú vzorku tvorilo 2906 respondentov, ktorými boli občania SR starší ako 18 rokov. Tab. č. 1 obsahuje charakteristiku výskumnej vzorky na základe parametrov pohlavie (F1), vzdelanie (F2), vek (F3), zamestnanie (F4) a trvalé bydlisko (F5), obr. č. 1 znázorňuje zastúpenie regiónov Slovenska v prieskume.

\begin{tabular}{|c|c|}
\hline \multicolumn{2}{|l|}{ Pohlavie (F1) } \\
\hline Ženy & $60 \%$ \\
\hline Muži & $40 \%$ \\
\hline \multicolumn{2}{|l|}{ Dosiahnuté vzdelanie (F2) } \\
\hline Základné & $1 \%$ \\
\hline Stredoškolské & $68 \%$ \\
\hline Vysokoškolské & $31 \%$ \\
\hline \multicolumn{2}{|l|}{ Vek (F3) } \\
\hline $18-25$ rokov & $33 \%$ \\
\hline $26-35$ rokov & $38 \%$ \\
\hline $36-45$ rokov & $17 \%$ \\
\hline $46-55$ rokov & $9 \%$ \\
\hline $56-65$ rokov & $2,7 \%$ \\
\hline viac ako 65 rokov & $0,3 \%$ \\
\hline \multicolumn{2}{|l|}{ Zamestnanie (F4) } \\
\hline Študent denného štúdia & $8 \%$ \\
\hline Zamestnanec-manuálne pracujúci & $15 \%$ \\
\hline Zamestnanec - duševne pracujúci & $47 \%$ \\
\hline Podnikatel', živnostník & $12 \%$ \\
\hline V domácnosti & $2 \%$ \\
\hline Nezamestnaný & $5 \%$ \\
\hline Iné zamestnanie & $9 \%$ \\
\hline Dôchodca & $2 \%$ \\
\hline \multicolumn{2}{|l|}{ Trvalé bydlisko - kraj (F5) } \\
\hline Bratislavský & $21 \%$ \\
\hline Trnavský & $10 \%$ \\
\hline Trenčiansky & $10 \%$ \\
\hline Nitriansky & $19 \%$ \\
\hline Banskobystrický & $16 \%$ \\
\hline Žilinský & $12 \%$ \\
\hline
\end{tabular}




\begin{tabular}{|l|l|}
\hline Prešovský & $8 \%$ \\
\hline Košický & $4 \%$ \\
\hline
\end{tabular}

Tab. č. 1: Charakteristika výskumnej vzorky

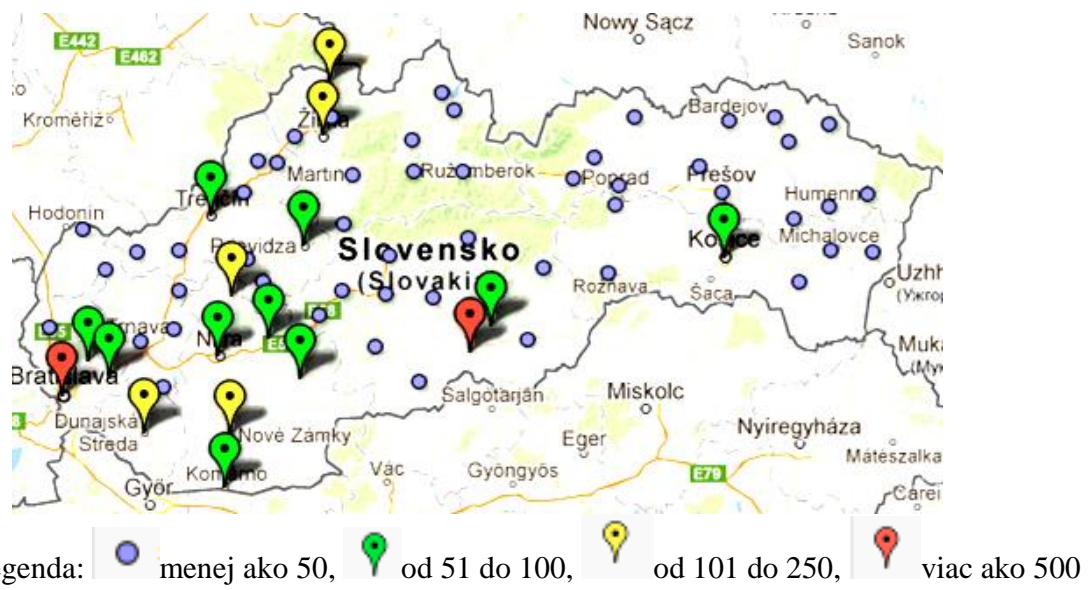

Obr. č. 1: Zastúpenie regiónov Slovenska v prieskume

\subsection{Sumarizácia výsledkov}

Stupeň ovládania jednotlivých ukazovatel'ov respondenti určovali na základe samohodnotenia, pričom vychádzali zo stanovenej stupnice. Ukazovatele úrovne digitálnych zručnosti boli hodnotené na stupnici od 1 do 5 , pričom hodnotenie 1 zodpovedalo „ovládam vel'mi dobre“, hodnotenie 5 ,neovládam vôbec“. Podiely hodnotení respondentov v rozmedzí 1 až 5 sú znázornené v grafe č. 1: 


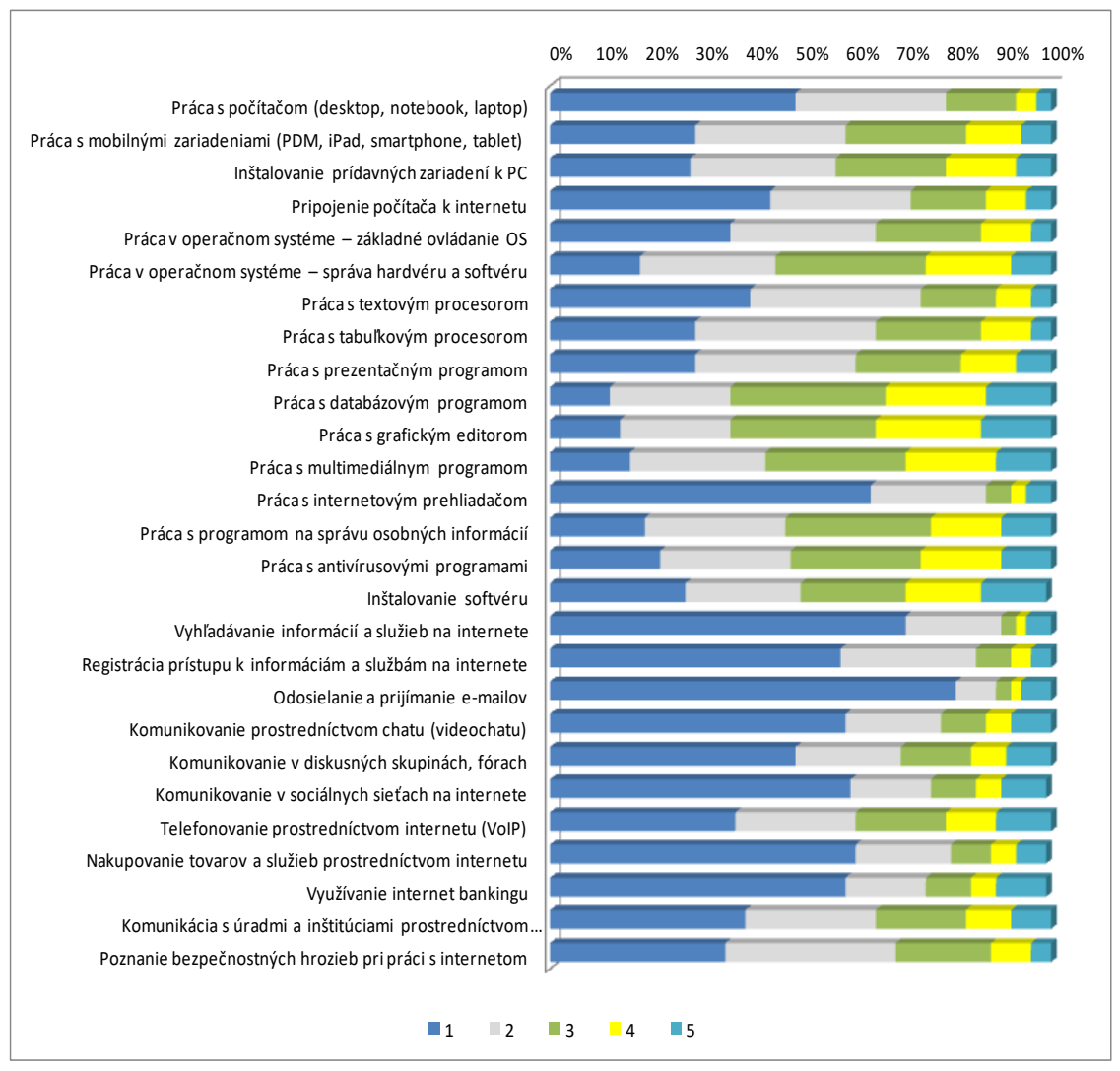

Graf č. 1: Sumarizácia hodnotení respondentov

\subsection{Výsledky deskriptívnej analýzy}

Vybrané výsledky deskriptívnej analýzy (priemery a smerodajné odchýlky vstupných premenných) sú znázornené v tab. č. 2. V skupine ukazovatel’ov - hardvér sa hodnoty pohybujú od 1,82 „Práca s počítačom (desktop, notebook, laptop)“ do 2,42 v ukazovateli „Inštalovanie prídavných zariadení k PC“, v skupine ukazovatel'ov - softvér od 1,61 „Práca internetovým prehliadačom“ do 2,99 „Práca s databázovým programom“ a v kategórii práca v prostredí internetu od,1,43 „Odosielanie a prijímanie e-mailov“ do 2,34 pre „Telefonovanie prostredníctvom internetu“. Priemery väčšiny ukazovatel’ov v skúmaných kategóriách (hardvér, softvér a práca v prostredí internetu) sa pohybujú doprava od hodnotenia 1 okolo stredu navrhovanej škály a majú mierne l'avé šikmé rozloženie. Smerodajná odchýlka vo všetkých skúmaných kategóriách sa nachádza medzi hodnotou 1 „Vyhl'adávanie informácií a služieb na internete“ a 1,74 pre „Komunikovanie v sociálnych siet'ach na internete“" 


\begin{tabular}{|c|c|c|c|c|}
\hline Kat. & \multicolumn{2}{|c|}{ Ukazovatele } & Priemer & Sm. odch. \\
\hline \multirow{4}{*}{ 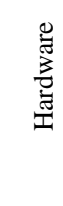 } & A1 & Práca s počítačom (desktop, notebook, laptop) & 1,82 & 1,02 \\
\hline & $\mathrm{A} 2$ & $\begin{array}{l}\text { Práca s mobilnými zariadeniami (PDM, iPad, } \\
\text { smartphone, tablet) }\end{array}$ & 2,36 & 1,19 \\
\hline & A3 & Inštalovanie prídavných zariadení k PC & 2,42 & 1,22 \\
\hline & A4 & Pripojenie počítača $\mathrm{k}$ internetu & 2,04 & 1,19 \\
\hline \multirow{12}{*}{$\sum_{\infty}^{0}$} & B1 & Práca v operačnom systéme - základné ovládanie OS & 2,19 & 1,16 \\
\hline & $\mathrm{B} 2$ & $\begin{array}{l}\text { Práca v operačnom systéme - správa hardvéru a } \\
\text { softvéru }\end{array}$ & 2,72 & 1,19 \\
\hline & B3 & Práca s textovým procesorom & 1,99 & 1,08 \\
\hline & B4 & Práca s tabul'kovým procesorom & 2,24 & 1,11 \\
\hline & B5 & Práca s prezentačným programom & 2,33 & 1,19 \\
\hline & B6 & Práca s databázovým programom & 2,99 & 1,20 \\
\hline & B7 & Práca s grafickým editorom & 2,98 & 1,24 \\
\hline & B8 & Práca s multimediálnym programom & 2,82 & 1,24 \\
\hline & B9 & Práca s internetovým prehliadačom & 1,61 & 1,04 \\
\hline & B10 & Práca s programom na správu osobných informácií & 2,69 & 1,23 \\
\hline & B11 & Práca s antivírusovými programami & 2,65 & 1,26 \\
\hline & B12 & Inštalovanie softvéru & 2,64 & 1,37 \\
\hline \multirow{11}{*}{ 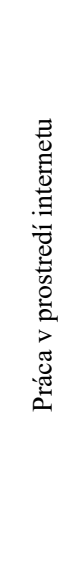 } & $\mathrm{C} 1$ & Vyhl'adávanie informácií a služieb na internete & 1,50 & 1,00 \\
\hline & $\mathrm{C} 2$ & $\begin{array}{l}\text { Registrácia prístupu k informáciám a službám na } \\
\text { internete }\end{array}$ & 1,70 & 1,05 \\
\hline & $\mathrm{C} 3$ & Odosielanie a prijímanie e-mailov & 1,43 & 1,14 \\
\hline & $\mathrm{C} 4$ & Komunikovanie prostredníctvom chatu (videochatu) & 1,83 & 1,24 \\
\hline & $\mathrm{C} 5$ & Komunikovanie v diskusných skupinách, fórach & 2,05 & 1,70 \\
\hline & C6 & Komunikovanie v sociálnych siet’ach na internete & 1,88 & 1,74 \\
\hline & $\mathrm{C} 7$ & Telefonovanie prostredníctvom internetu (VoIP) & 2,34 & 1,35 \\
\hline & $\mathrm{C} 8$ & Nakupovanie tovarov a služieb prostredníctvom internetu & 1,77 & 1,19 \\
\hline & C9 & Využívanie internetbankingu & 1,91 & 1,35 \\
\hline & $\mathrm{C} 10$ & $\begin{array}{l}\text { Komunikácia } \quad \mathrm{s} \text { úradmi } \\
\text { prostredníctvom elektronických formulárov }\end{array}$ & 2,20 & 1,36 \\
\hline & $\mathrm{C} 11$ & Poznanie bezpečnostných hrozieb pri práci s internetom & 2,14 & 1,11 \\
\hline
\end{tabular}

Pozn: najlepšie a najhoršie výsledky sú zvýraznené šedou farbou

Tab. č. 2: Vybrané výsledky jednotlivých ukazovatel'ov 
Celkové výsledky stanovené podl’a jednotlivých faktorov F1, ...F5 znázorňuje tab. č. 3:

\begin{tabular}{|c|c|c|c|c|}
\hline & Faktory & Priemer & Smer. odch. & Štd. chyba \\
\hline \multirow[t]{3}{*}{ F1 } & \multicolumn{4}{|l|}{ Pohlavie } \\
\hline & Ženy & 2,28 & 0,768 & 0,018 \\
\hline & Muži & 2,06 & 0,875 & 0,026 \\
\hline \multirow[t]{4}{*}{$\mathrm{F} 2$} & \multicolumn{4}{|l|}{ Dosiahnuté vzdelanie } \\
\hline & Základné & 2,73 & 1,211 & 0,214 \\
\hline & Stredoškolské & 2,27 & 0,815 & 0,018 \\
\hline & Vysokoškolské & 2,01 & 0,779 & 0,026 \\
\hline \multirow[t]{7}{*}{ F3 } & \multicolumn{4}{|l|}{ Vek } \\
\hline & $18-25$ rokov & 2,08 & 0,731 & 0,024 \\
\hline & $26-35$ rokov & 2,10 & 0,773 & 0,023 \\
\hline & $36-45$ rokov & 2,25 & 0,821 & 0,037 \\
\hline & $46-55$ rokov & 2,57 & 0,906 & 0,056 \\
\hline & $56-65$ rokov & 3,12 & 1,039 & 0,121 \\
\hline & viac ako 65 rokov & 3,69 & 1,179 & 0,417 \\
\hline \multirow[t]{9}{*}{ F4 } & \multicolumn{4}{|l|}{ Zamestnanie } \\
\hline & Študent denného štúdia & 2,00 & 0,714 & 0,044 \\
\hline & $\begin{array}{l}\text { Zamestnanec-manuálne } \\
\text { pracujúci }\end{array}$ & 2,38 & 0,855 & 0,039 \\
\hline & $\begin{array}{l}\text { Zamestnanec - duševne } \\
\text { pracujúci }\end{array}$ & 2,10 & 0,769 & 0,020 \\
\hline & Podnikatel', živnostník & 2,18 & 0,863 & 0,044 \\
\hline & V domácnosti & 2,37 & 0,698 & 0,074 \\
\hline & Nezamestnaný & 2,30 & 0,792 & 0,058 \\
\hline & Iné zamestnanie & 2,43 & 0,964 & 0,170 \\
\hline & Dôchodca & 3,47 & 0,937 & 0,141 \\
\hline \multirow[t]{9}{*}{ F5 } & \multicolumn{4}{|l|}{ Trvalé bydlisko (okres) } \\
\hline & Bratislava & 2,14 & 0,793 & 0,031 \\
\hline & Trnava & 2,25 & 0,891 & 0,053 \\
\hline & Trenčín & 2,28 & 0,867 & 0,052 \\
\hline & Nitra & 2,17 & 0,827 & 0,035 \\
\hline & Banská Bystrica & 2,26 & 0,787 & 0,037 \\
\hline & Žilina & 2,13 & 0,785 & 0,043 \\
\hline & Prešov & 2,19 & 0,815 & 0,054 \\
\hline & Košice & 2,15 & 0,837 & 0,075 \\
\hline
\end{tabular}

Tab. č. 3: Vybrané výsledky podl’a jednotlivých faktorov

Ked’že celkové výsledky dostatočne nepreukazujú vplyv jednotlivých faktorov na úroveň digitálnych znalostí a zručností, d'alšiemu skúmaniu sme podrobili ukazovatele, ktoré v každej oblasti dosiahli extrémne hodnoty priemeru, za účelom zistenia štatistickej 
významnosti vplyvu faktorov. Skúmanými ukazovatel'mi sú A1, A3, B9, B6, C3, C7 (extrémne hodnoty z tab. č. 2) a ovplyvňujúcimi faktormi sú pohlavie, vzdelanie, vek, zamestnanie a región bydliska.

Výsledky overenia štatistickej významnosti odlišnosti odpovedí mužov a žien na základe dvojvýberového $\mathrm{t}$ - testu a sú v tab. č. 4 .

\begin{tabular}{|c|c|c|c|c|c|c|c|}
\hline \multirow[t]{2}{*}{ Indicator } & \multicolumn{2}{|c|}{$\begin{array}{l}\text { Levene's test for } \\
\text { Equality of variances }\end{array}$} & \multirow[t]{2}{*}{$\mathrm{t}$ - value } & \multirow[t]{2}{*}{$\mathrm{p}$ - value } & \multirow[t]{2}{*}{ Mean } & \multicolumn{2}{|c|}{$\begin{array}{l}\quad 95 \% \\
\text { Confidence Interval } \\
\text { of the Difference }\end{array}$} \\
\hline & $\mathrm{F}$ & Sig. & & & & Lower & Upper \\
\hline A1 & 2,127 & 0,145 & $\begin{array}{l}3,846 \\
3,830\end{array}$ & $\begin{array}{l}0,000 \\
0,000\end{array}$ & $\begin{array}{l}1,73 \\
1,88\end{array}$ & $\begin{array}{l}0,224 \\
2,224\end{array}$ & $\begin{array}{l}0,073 \\
0,072\end{array}$ \\
\hline $\mathrm{A} 3$ & 1,595 & 0,207 & $\begin{array}{l}15,831 \\
15,711\end{array}$ & $\begin{array}{l}0,000 \\
0,000\end{array}$ & $\begin{array}{l}1,99 \\
2,70\end{array}$ & $\begin{array}{l}0,617 \\
0,616\end{array}$ & $\begin{array}{l}0,792 \\
0,792\end{array}$ \\
\hline B9 & 0,289 & 0,591 & $\begin{array}{l}1,494 \\
1,493\end{array}$ & $\begin{array}{l}0,135 \\
0,135\end{array}$ & $\begin{array}{l}1,57 \\
1,63\end{array}$ & $\begin{array}{l}0,136 \\
0,137\end{array}$ & $\begin{array}{l}0,018 \\
0,018\end{array}$ \\
\hline B6 & 15,112 & 0,000 & $\begin{array}{l}2,628 \\
2,663\end{array}$ & $\begin{array}{l}0,009 \\
0,008\end{array}$ & $\begin{array}{l}2,91 \\
3,03\end{array}$ & $\begin{array}{l}0,031 \\
0,032\end{array}$ & $\begin{array}{l}0,211 \\
0,210\end{array}$ \\
\hline $\mathrm{C} 3$ & 1,124 & 0,289 & $\begin{array}{l}0,635 \\
0,641\end{array}$ & $\begin{array}{l}0,525 \\
0,521\end{array}$ & $\begin{array}{l}1,49 \\
1,51\end{array}$ & $\begin{array}{l}0,099 \\
0,098\end{array}$ & $\begin{array}{l}0,050 \\
0,050\end{array}$ \\
\hline $\mathrm{C} 7$ & 16,516 & 0,000 & $\begin{array}{l}4,388 \\
4,447\end{array}$ & $\begin{array}{l}0,000 \\
0,000\end{array}$ & $\begin{array}{l}2,21 \\
2,43\end{array}$ & $\begin{array}{l}0,325 \\
0,323\end{array}$ & $\begin{array}{l}0,124 \\
0,125\end{array}$ \\
\hline
\end{tabular}

Tab. č. 4 : Overenie štatistickej významnosti odlišnosti odpovedí mužov a žien

Predpokladali sme, že rôznost' odpovedí mužov a žien sa na celkovej úrovni digitálnej gramotnosti štatisticky významne nepodiel’a. Aplikovaním dvojvýberového t testu bola hodnota p v prípade ukazovatel'ov A1 - práca s počítačom (desktop, notebook, laptop), A3 - inštalovanie prídavných zariadení a C7 - telefonovanie prostredníctvom internetu (VoIP) minimálna, čo indikuje štatistickú významnost' rozdielnosti odpovedí mužov a žien, pričom vo všetkých 3 prípadoch vyššie hodnotenie dosahujú muži. V prípade ukazovatel’ov B9 a C3 sa štatistická významnost' nepreukázala $(\mathrm{p}>0,05)$.

Faktor vzdelania sa tiež podiel'a na ovplyvňovaní úrovne digitálnych zručností, a to konkrétne takto (uvádzame priemerné hodnoty $\mathrm{z}$ tab. č. 3) : základné vzdelanie $-2,73$; stredoškolské $-2,27$; vysokoškolské $-2,01$. Pozitívny vplyv so zvyšujúcim sa stupňom dosiahnutého vzdelania sme zaznamenali pri všetkých ukazovatel'och, kedy priemerné hodnoty u respondentov so základným vzdelaním sa nachádzali na úrovni 2,20 až 3,35. $\mathrm{S}$ dosiahnutým vyšším stupňom vzdelania dochádza $\mathrm{k}$ zvyšovaniu úrovne digitálnych zručností, kde sme zaznamenali zlepšenie priemerného hodnotenia v priemere o 0,97 ( $v$ absolútnom vyjadrení sa zmena prejavovala od 0,70 až po 1,66 hodnoty). Najväčšia zmena sa preukázala pri ukazovateli „,využívanie internetbankingu“. Štatistickú významnost' vplyvu dosiahnutého vzdelania na výšku jednotlivých ukazovatel’ov sme 
overovali pomocou jednoduchej analýzy rozptylu (one way ANOVA), výsledky ktorého sú v tab. č. 5. Výsledky potvrdili štatisticky významnú závislost' v prípade všetkých ukazovatel'ov okrem jedného, a to C7 - telefonovanie prostredníctvom internetu (VoIP). $\mathrm{V}$ tomto prípade je hodnota $\mathrm{p}>0,05$, a teda závislost' ukazovatel'a $\mathrm{C} 7$ od dosiahnutého vzdelania nedosahuje štatisticky významné hodnoty.

\begin{tabular}{|c|c|c|c|c|c|c|}
\hline \multicolumn{2}{|c|}{ Indicator } & $\begin{array}{l}\text { Sum of } \\
\text { Squares }\end{array}$ & df & $\begin{array}{l}\text { Mean } \\
\text { Square }\end{array}$ & $\mathrm{F}$ & $\begin{array}{l}\mathrm{P} \\
\text { value }\end{array}$ \\
\hline A1 & $\begin{array}{l}\text { Between Groups } \\
\text { Within Groupas } \\
\text { Total, }\end{array}$ & $\begin{array}{l}45,560 \\
1847,927 \\
1893,486 \\
\end{array}$ & $\begin{array}{l}2 \\
1827 \\
1829 \\
\end{array}$ & $\begin{array}{l}22,780 \\
1,011 \\
\end{array}$ & 22,522 & 0,000 \\
\hline A3 & $\begin{array}{l}\text { Between Groups } \\
\text { Within Groupas } \\
\text { Total }\end{array}$ & $\begin{array}{l}59,860 \\
4259,702 \\
4319,561\end{array}$ & $\begin{array}{l}2 \\
2888 \\
2890\end{array}$ & $\begin{array}{l}29,930 \\
1,475\end{array}$ & 20,292 & 0,000 \\
\hline B9 & $\begin{array}{l}\text { Between Groups } \\
\text { Within Groupas } \\
\text { Total }\end{array}$ & $\begin{array}{l}28,248 \\
3107,413 \\
3135,661\end{array}$ & $\begin{array}{l}2 \\
2888 \\
2890\end{array}$ & $\begin{array}{l}17,124 \\
1,076\end{array}$ & 13,127 & 0,000 \\
\hline B6 & $\begin{array}{l}\text { Between Groups } \\
\text { Within Groupas } \\
\text { Total }\end{array}$ & $\begin{array}{l}97,587 \\
4059,803 \\
4157,390\end{array}$ & $\begin{array}{l}2 \\
2888 \\
2890\end{array}$ & $\begin{array}{l}48,793 \\
1,406\end{array}$ & 34,710 & 0,000 \\
\hline $\mathrm{C} 3$ & $\begin{array}{l}\text { Between Groups } \\
\text { Within Groupas } \\
\text { Total }\end{array}$ & $\begin{array}{l}25,929 \\
2882,814 \\
2908,743 \\
\end{array}$ & $\begin{array}{l}2 \\
2888 \\
2890\end{array}$ & $\begin{array}{l}12,965 \\
0,998\end{array}$ & 12,988 & 0,000 \\
\hline $\mathrm{C} 7$ & $\begin{array}{l}\text { Between Groups } \\
\text { Within Groupas } \\
\text { Total }\end{array}$ & $\begin{array}{l}16,689 \\
5266,709 \\
5283,398\end{array}$ & $\begin{array}{l}2 \\
2888 \\
2890\end{array}$ & $\begin{array}{l}8,345 \\
1,824\end{array}$ & 4,576 & 0,100 \\
\hline
\end{tabular}

Tab. č. 5: Overenie štatistickej významnosti odlišnosti odpovedi na základe vzdelania respondentov

Rovnaký postup sme zvolili aj v prípade d’alších faktorov, u ktorých uvedieme len výsledky vykonanej analýzy.

Na základe priemerných hodnôt z tab. č. 3 možno konštatovat', že dopad faktora vek sa prejavil na úrovni digitálnych zručností tak, že s pribúdajúcim vekom úroveň digitálnych zručností klesala. Pri faktore vek sme zaznamenali aj najnižšiu úroveň zo všetkých ukazovatel'ov, kde vo vekovej skupine nad 65 rokov je priemerná hodnota ukazovatel'a „využívanie internetbankingu“ na úrovni 4,75. Výsledky viacfaktorovej analýzy potvrdili, že vplyv veku na hodnotu jednotlivých ukazovatel’ov je štatisticky významný, pretože pri všetkých ukazovatel'och bola hodnota $p<0,05$.

Pri skúmaní ekonomickej aktivity respondentov a dosiahnutej úrovne digitálnej gramotnosti zaujímavým zistením je dosiahnutie vy̌̌šej úrovne gramotnosti $\mathrm{u}$ nezamestnaných jednotlivcov $\mathrm{v}$ porovnaní $\mathrm{s}$ jednotlivcami $\mathrm{v}$ domácnosti a manuálne pracujúcimi, z čoho môžeme predpokladat', že v našej vzorke nezamestnaných je nižší 
podiel respondentov, ktorí ak by boli zamestnaní, patrili by do kategórie manuálne pracujúcich. Najnižšia úroveň v kategórii dôchodcov korešponduje so zistením, ktoré sme nadobudli pri analýzach jednotlivých vekových skupín. Pri analyzovaní vybraných ukazovatel'ov sa jednotlivé skupiny podl'a ekonomickej aktivity odlišuje rôzne. Najvyrovnanejšie hodnoty sme zaznamenali pri ukazovateli odosielania a prijímania e-mailov, čo sa dalo logicky predpokladat'. Tu sme zaznamenali aj najvyšší podiel výbornej úrovne digitálnych zručnosti až u 4 skupín do hodnoty 1,5 a to (zoradené podl'a úrovne): zamestnanec - duševný pracovník, študent denného štúdia, v domácnosti a podnikatel', živnostník. Očakávaná najnižšia úroveň v práci s databázovým softvérom, kde až 5 skupín sa nachádzaj nad úrovňou 3, avšak ani jedna skupina nedosahuje výborné hodnoty, a všetky tieto ostatné kategórie (zamestnanec - duševný pracovník, študent denného štúdia, podnikatel' živnostník) sa nachádzajú tesne pod úrovňou hodnoty 3 , v intervale od 2,83 až po 2,96 . Štatisticky významný vplyv ekonomickej aktivity respondentov na hodnotu vybraných ukazovatel'ov bol potvrdený viacfaktorovou analýzou, kedy v prípade všetkých ukazovatel'ov bola hodnota $\mathrm{p}<0,05$.

Regionálne hladisko sme skúmali $\mathrm{v}$ dvoch rovinách a to trvalé bydlisko respondentov a región $\mathrm{z}$ pohladu ich zamestnania, resp. d’alších ekonomických aktivít. Pri trvalom bydlisku sa celkové priemerné hodnoty pohybujú $\mathrm{v}$ intervaloch od 2,13 do 2,28 , podla zamestnania sú to hodnoty 2,11 až 2,31 . Z hladiska ekonomickej aktivity je najlepším regiónom Bratislavský kraj a naopak najhoršie výsledky zaznamenáva Trnavský kraj. V porovnaní s trvalým pobytom, kde bol rozdiel zaznamenaný aj na prvej pozícii - Žilinský kraj $(2,13)$ a tiež na poslednej pozícii - Trenčiansky kraj $(2,33)$. Štatisticky významný vplyv trvalého bydliska, ako aj pracoviska, na hodnotu vybraných ukazovatel'ov bol potvrdený aj $\mathrm{v}$ týchto prípadoch, kedy bola hodnota $\mathrm{p}$ u všetkých ukazovatel'ov $\mathrm{p}<0,05$. Zo získaných hodnôt vyplýva štatisticky významná závislost', na ktorej sa podiel’a najmä Bratislavský kraj.

\section{Diskusia a záver}

Výskumná štúdia mala za ciel' posúdit' úroveň digitálnej gramotnosti na Slovensku a identifikovat' faktory podiel'ajúce sa na vytváraní digitálnej priepasti. Najvyššiu úroveň digitálnej gramotnosti sme identifikovali v oblasti práce s internetom, naopak najnižšiu v zručnostiach ovládania softvérových aplikácií. Digitálnu priepast' ovplyvňujú viaceré faktory, vplyv ktorých sme $\mathrm{v}$ rámci výskumu posudzovali. Ich podiel na vytváraní digitálnej priepasti možno identifikovat' takto: faktor pohlavie sa preukázal ako štatisticky významný pri ukazovatel'och $\mathrm{z}$ oblasti hardvéru v neprospech žien. Pri vzdelaní je tento vplyv významný vo všetkých skúmaných oblastiach, kde respondenti so základným vzdelaním dosahovali najnižšie hodnoty. Z hladiska veku bolo potvrdené, že znevýhodnení sú predovšetkým starší občania vo všetkých skúmaných ukazovatel’och. Vplyv faktora región je štatisticky významný, pričom výrazné rozdiely boli zaznamenané hlavne v porovnaní Bratislavského regiónu s ostatnými regiónmi. Pri skúmaní možností získavania zručností z oblasti IKT vysoko prevyšovalo samoštúdium nad tradičnými formami vzdelávania.

Ďalším ciel'om nášho skúmania bolo zistit' aj to, kde respondenti nadobudli svoje znalosti a zručnosti, pričom toto skúmanie sme súhrnne realizovali pre 3 základné oblasti - hardvér, softvér a práca v prostredí internetu. Súhrnné vyhodnotenie prinieslo tieto 
zaujímavé výsledky: až $72 \%$ respondentov uviedlo, že tieto zručnosti nadobudli samoštúdiom (v oblasti hardvéru - $68 \%$, softvéru - $62 \%$, internetu $-87 \%$ ), na základnej a strednej škole $12 \%$, na vysokej škole $9 \%$, v kurzoch $4 \%$, v zamestnaní $3 \%$, kombináciou škola, kurzy, samoštúdium $0,6 \%$.

Pri podrobnejšom analyzovaní výsledkov vo vzt’ahu k ukončenému stupňu vzdelania sme zistili tieto skutočnosti: respondenti, ktorí mali ukončené základné vzdelanie uvádzali, že tieto znalosti a zručnosti nadobudli samoštúdiom $72 \%$; na základnej škole $25 \%$; v zamestnaní $3 \%$. Respondenti s ukončeným stredoškolským vzdelaním ich nadobudli: 87 \% samoštúdiom; 7 \% na základnej a strednej škole; $1,6 \%$ na vysokej škole zatial' neukončenej; $1,7 \%$ v kurzoch; $1,5 \%$ v zamestnaní. V skupine respondentov s vysokoškolských vzdelaním tiež dominuje samoštúdium $85 \%$; na vysokej škole $8 \%$; na základnej a strednej škole $3 \%$; v kurzoch $2 \%$; v zamestnaní $1 \%$.

Získané výsledky hovoria o tom, že z hl'adiska štruktúry, ako aj zrejme z obsahového hladiska, je vzdelávací systém v SR aj napriek mnohým projektom a snahám o jeho modernizáciu nezosúladený so súčasným digitálnym pracovným trhom a predovšetkým s jeho požiadavkami, ako aj celkovo s digitálnou spoločnost'ou. Nasvedčuje tomu aj skutočnost', že až $72 \%$ respondentov získalo väčšinu znalostí a zručností z oblasti IKT v rámci neformálneho vzdelávania, len $21 \%$ prostredníctvom formálneho vzdelávania na vysokých, stredných ako aj základných školách a $7 \%$ neformálnym vzdelávaním. Skutočnost', že až $72 \%$ uviedlo, že tieto gramotnosti získali samoštúdiom, svedčí aj o tom, že ich ekonomická aktivita, ako aj d’alší spoločenský život v digitálnej spoločnosti, si tieto znalosti a zručnosti vyžadujú.

Závery nášho výskumu potvrdili, že aj na Slovensku ovplyvňujú vytváranie digitálnej priepasti predpokladané faktory, ktorými sú predovšetkým vek a vzdelanie.

\section{Pod'akovanie}

Táto práca bola podporená Vedeckou agentúrou SR VEGA prostredníctvom finančnej podpory projektu č. 1/0933/14.

\section{Literatúra}

Bolek, V. (2015). Proces vzdelávania študentov v oblasti IKT pre manažérsku prax. Dostupné z: $\quad$ http://jtie,upol,cz/artkey/jti-2015020006_PROCES_VZDELAVANIA_STUDENTOV_V_OBLASTI_IKT_PRE_MANAZE RSKU_PRAX,php.

ECDL Foundation. (2010). Building a Digitally Europe through Education (Budovanie digitálne gramotnej Európy prostrednictvom vzdelávania). Dostupné $\mathrm{z} \quad$ : http://www.ecdl.sk/zaujimave-dokumenty

Európska komisia. (2010). Digitálna agenda pre Európu: čo by mi to mohlo priniest? Dostupné z: http://europa,eu/rapid/press-release_MEMO-10-199_sk,htm.

Eurostat. (2012). Main statistical findings, Dostupné z: http://ec.europa.eu/eurostat/statistics-

explained/index.php/Digital_economy_and_society_statistics_-

_households_and_individuals\#Main_statistical_findings .

Eurostat. (2015). Information society statistics at regional level, Dostupné z: 
http://ec.europa.eu/eurostat/statistics-

explained/index.php/Information_society_statistics_at_regional_level .

Gavora, P. a kol. (2010). Elektronická učebnica pedagogického výskumu, [online], Bratislava: Univerzita Komenského, 2010. Dostupné z: http://www,emetodologia,fedu,uniba,sk/ ISBN 978-80-223-2951-4.

Gilster, P. (1997). Digital literacy, Chichester, John Wiley, New York.

Google Slovensko. (2014). Prieskum medzi Slovákmi: Bez internetu ani na krok? Dostupné z: http://googlepresssk,blogspot,sk/2014/05/prieskum-medzi-slovakmi-bezinternetu,html .

Gruszczynska, A., Merchant, G., \& Pountney, R. (2013). Digital Futures in Teacher Education: Exploring Open Approaches towards Digital Literacy. Electronic Journal of E-Learning. 11(3). 193-206.

OECD. (2004). OECD Information technology Outlook. OECD PUBLICATIONS. ISBN 92-64-01685-6.

Operačný program Informatizácia spoločnosti verzia 4.0, 14.6. 2012. Dostupné z: http://www,informatizacia,sk/624-menu/10598s.

Velšic, M. (2011). Digitálna gramotnost' na Slovensku 2011. Inštitút pre verejné otázky, Bratislava 2011. ISBN 978-80-89345-33-5. 